\title{
Highly Efficient Construction of Sugar-Fused Spirochromanono Pyrrolidines/Pyrrolizidines/Thiolizidines via 1,3-Dipolar Cycloaddi- tion of Azomethine Ylides
}

\author{
Sirisha Nallamala ${ }^{a}$ \\ Srikumar Mannem*b \\ Raghunathan Raghavachary*a \\ a Department of Organic Chemistry, University of Madras, \\ Guindy Campus, Chennai 600 025, India \\ ragharaghunathan@yahoo.com \\ ' Laurus Labs LTD, ICICI Knowledge Park, Turakapally, \\ Hyderabad 500078, India \\ sirisrimannem@gmail.com
}
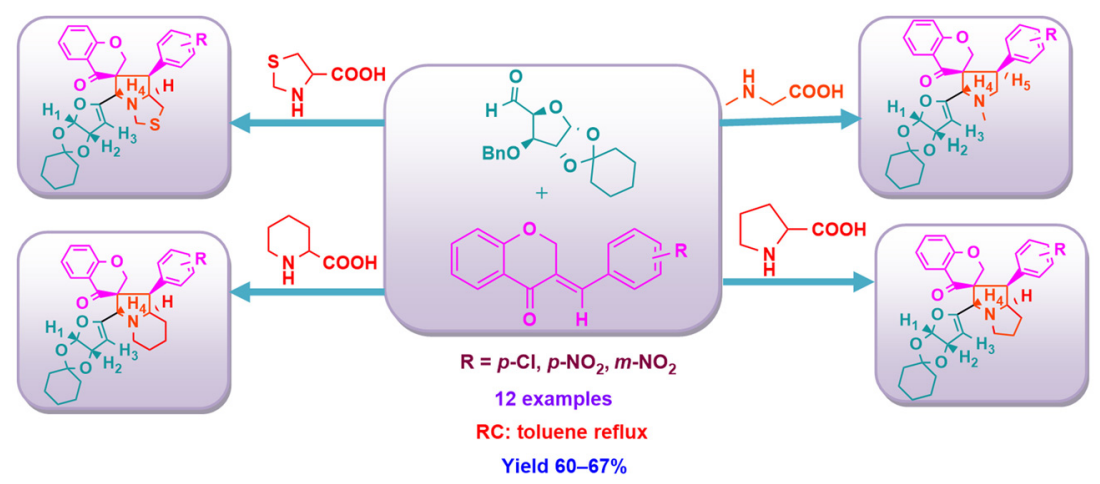

C: toluene reflux

Received: 29.05.2017

Accepted after revision: 11.07.2017

Published online: 01.08.2017

DOI: 10.1055/s-0036-1588520; Art ID: so-2017-d0018-I

License terms: cc)

Abstract A variety of sugar-fused chromanono pyrrolidines/pyrrolizidines/thiolizidines have been synthesized by intermolecular 1,3-dipolar cycloaddition reaction of azomethine ylides (generated from glucose aldehyde and different secondary amino acids) with various 3arylidene chroman-4-ones as dipolarophiles. The solvent effect on the 1,3-dipolar cycloaddition reaction is also studied.

Key words 1,3-dipolar cycloaddition, spirochromanones, glycosyl heterocycles, azomethine ylide, pyrrolidines

Cyclic glycosides are important as enzyme inhibitors and as chiral synthons that are suitable for the synthesis of many natural products. ${ }^{1}$ Enormous amounts of work on carbohydrate-based heterocycles has shown a diverse range of biological properties such as anticancer, ${ }^{2}$ antitumor, ${ }^{3}$ anti-influenza (H1N1), ${ }^{4}$ antimicrobial, ${ }^{5}$ and anti-HIV activity. ${ }^{6}$ The formation of heterocycles from carbohydrates is a much studied area in the synthetic organic field. ${ }^{7}$ However, five-membered heterocycles with one nitrogen atom in the ring are less readily available directly from carbohydrates. The most relevant approach for the synthesis of unnatural five-membered heterocycles from carbohydrates is by means of a 1,3-dipolar cycloaddition reaction. ${ }^{8}$ 1,3-Dipolar cycloadditions of sugar-derived compounds allow the synthesis of pyrrolidines, pyrrolizidines, isoxazoles, imidazoles, and imadazolidines. ${ }^{9}$

4-Chromanone is a privileged structure, and chromanones are important intermediates in organic synthesis. ${ }^{10}$ Spirochromanone derivatives have been found to exhibit a wide range of biological properties such as anti-inflammatory, antioxidant, ${ }^{11}$ antitubercular, ${ }^{12}$ antidiabetic ${ }^{13}$ and anti- microbial activities. ${ }^{14}$ Recent reports show that spirochromanone derivatives have been found to have a strong acetyl-CoA carboxylase (ACC) inhibiting effect (Figure 1). ${ }^{15}$
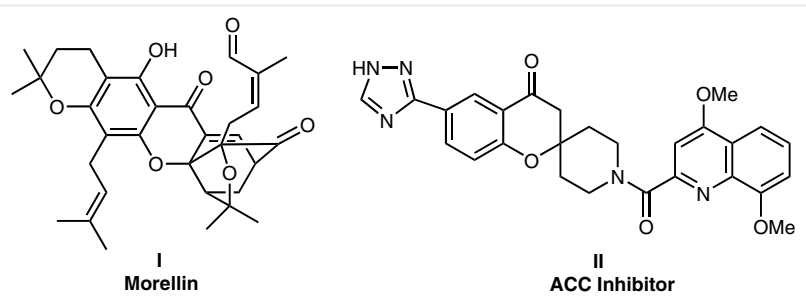

Figure 1 Representatives of bioactive spirochromanones

Molecular hybridization is the combination of two or more pharmacophores linked or fused with each other to create a new molecule, with each component enriching the biological properties when compared to the individuals. ${ }^{16}$ The potential applicability of 4-chromanone and carbohydrate scaffolds to such a strategy has led us to synthesize some new sugar-fused spirochromanone derivatives by using 1,3-dipolar cycloaddition chemistry.

The synthetic utility of carbohydrate scaffolds as dipolarophiles (azide, nitrone and nitrile oxide) has been well exploited in 1,3-dipolar cycloaddition chemistry, ${ }^{17}$ but the use of a carbohydrate scaffold as a dipole has not been well exploited. With a view to study the carbohydrate scaffold as an azomethine ylide, as well as in continuation of our endeavor towards the synthesis of novel heterocycles using 1,3-dipolar cycloaddition reactions, ${ }^{18}$ we report herein the synthesis of novel sugar-fused spirochromanono heterocycles by a one-pot, three-component 1,3-dipolar cycloaddition of azomethine ylides, obtained from glucose aldehyde and a range of secondary amino acids, with 3-arylidene chroman-4-ones. 

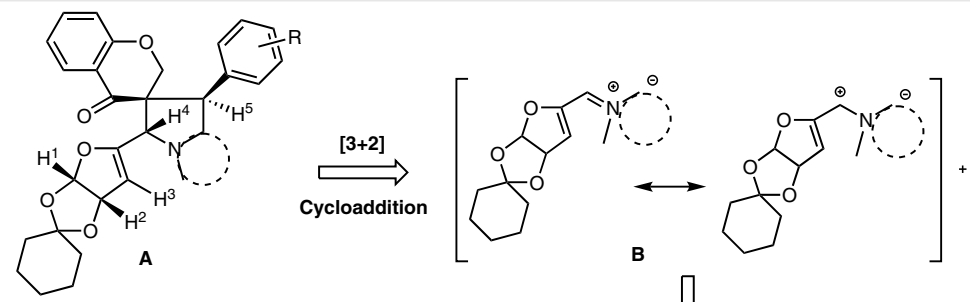<smiles>O=C1/C(=C\c2ccccc2)COc2ccccc21</smiles><smiles>O=CC1OC2OC3(CCCCC3)OC2C1[18O]</smiles><smiles>O=C1CCOc2ccccc21</smiles>

E

Scheme 1 Retrosynthetic approach for the synthesis of sugar-fused spirochromanono heterocycles

As shown in Scheme 1, the construction of a spiropyrrolidine ring system $(\mathrm{A})$ was envisaged from a 1,3-cycloaddition reaction involving an azomethine ylide (B) with an external olefin (C), while templates for such cycloaddition could be conveniently realized from 4-chromanone (E) and sugar aldehyde (D).

The synthesis began with the known $O$-benzyl sugar aldehyde 3 and various 3-arylidene chroman-4-ones as starting materials, which were prepare according to reported procedures. ${ }^{19,20}$

0 -Benzyl tethered sugar aldehyde 3 , when reacted with sarcosine $\mathbf{2}$ and 3-arylidene chroman-4-ones $\mathbf{1 a - c}$ in refluxing toluene under Dean-Stark conditions, yielded novel glycosyl spirochromanonopyrrolidines $\mathbf{5 a - c}$ through cycloaddition reaction of azomethine ylide generated from sugar aldehyde and sarcosine with 3-arylidene chroman-4ones (Scheme 2). That the benzyloxy group elimination had occurred during the reaction was confirmed by mass spectrometry and NMR spectroscopic analysis of the product. The cycloadduct $\mathbf{5 b}$ revealed a peak in the mass spectrum at $m / z 519$ instead of the expected $m / z 627$, which indicates the elimination of the benzyloxy group. This was further confirmed from the ${ }^{1} \mathrm{H}$ NMR spectrum, which revealed the absence of a signal due to the benzylic protons $\left(\mathrm{CH}_{2} \mathrm{Ph}\right)$. Furthermore, only three protons were observed in the furanose moiety. Based on the above observations, the structure of the compound was assigned as the alkenyl sugarfused chromanono pyrrolidine $\mathbf{5 b} .^{21}$

The IR spectrum of product $\mathbf{5 b}$ exhibited a peak at $1679 \mathrm{~cm}^{-1}$ characteristic of a chromanone carbonyl carbon. The absorption bands at 1554 and $1350 \mathrm{~cm}^{-1}$ were attributed to the nitro group.

The ${ }^{1} \mathrm{H}$ NMR spectrum of $\mathbf{5 b}$ showed a sharp singlet at $\delta$ $=2.40 \mathrm{ppm}$ for the $\mathrm{N}$-methyl protons. The $\mathrm{H} 4$ proton of the pyrrolidine ring was observed as a singlet at $\delta=3.77 \mathrm{ppm}$, which clearly shows the regioselectivity of the cycloadduct. The H5 proton was observed to resonate as a doublet of doublets at $\delta=3.41(J=3.6,9.3 \mathrm{~Hz})$, which strongly
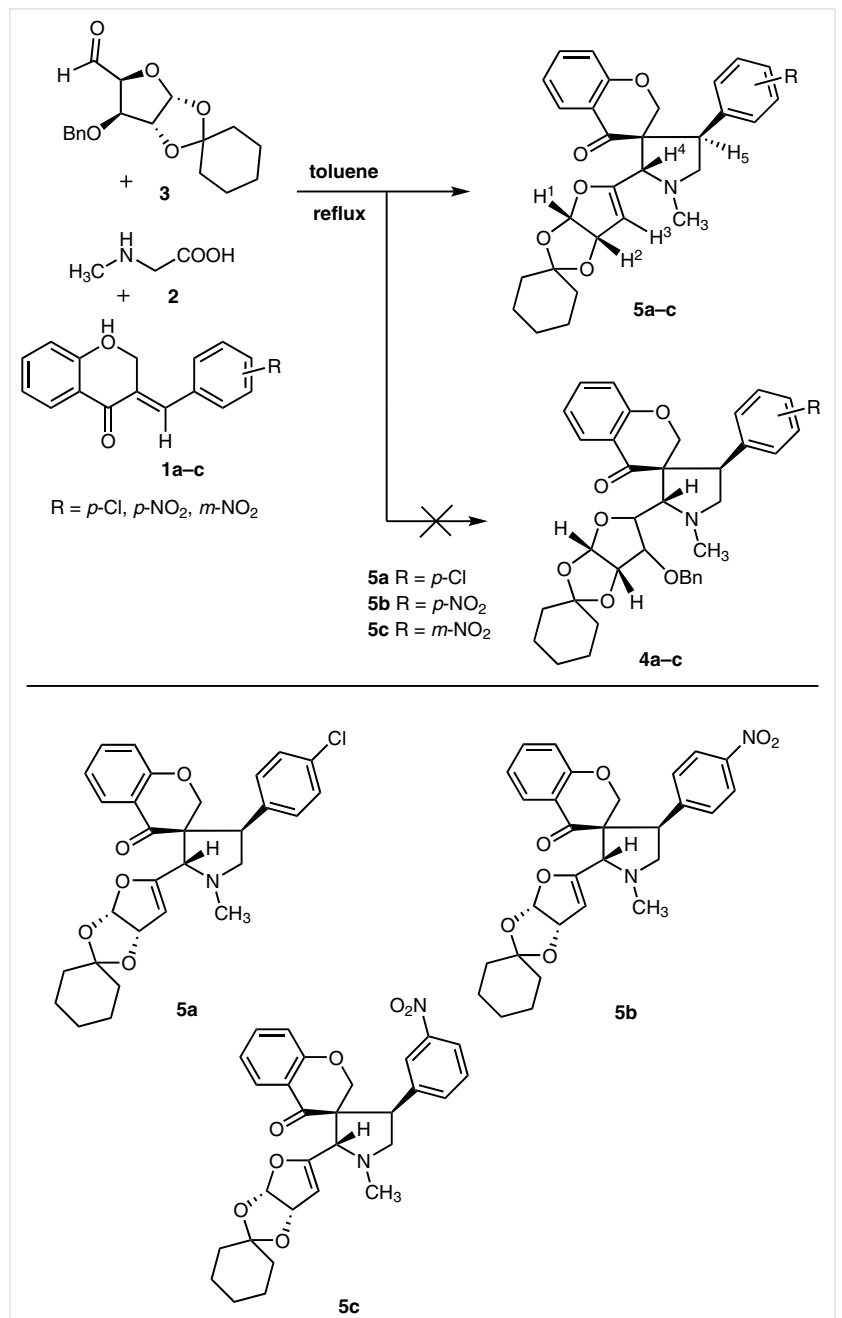

Scheme 2 Synthesis of sugar-fused spirochromanono pyrrolidines 
supports the structure of the proposed regioisomer. Two well-separated doublets at $\delta=3.93$ and $4.27 \mathrm{ppm}$ with a coupling constant of $12.3 \mathrm{~Hz}$ corresponded to the $\mathrm{CH}_{2}$ protons of the chromanone moiety.

In the ${ }^{1} \mathrm{H}^{1} \mathrm{H}$ COSY spectrum of $\mathbf{5 b}$, the proton at $\delta=$ $5.91 \mathrm{ppm}$ showed a correlation with the proton at $\delta=$ $5.09 \mathrm{ppm}$. Additionally, the proton at $\delta=5.09 \mathrm{ppm}$ showed a correlation with the proton at $\delta=5.14 \mathrm{ppm}$ in addition to that with the proton at $\delta=5.91 \mathrm{ppm}$. Hence, we could assign the signals at $\delta=5.14 \mathrm{ppm}$ to $\mathrm{H} 2$ and $\delta=5.14 \mathrm{ppm}$ to H3. The stereochemistry of the cycloadduct $\mathbf{5 b}$ was deduced on the basis of 2D NOESY experiments. There is no NOESY correlation between $\mathrm{H} 4$ and $\mathrm{H} 5$ of $\mathbf{5 b}$, which at least supports trans stereochemistry.

The ${ }^{13} \mathrm{C}$ NMR spectrum of $\mathbf{5 b}$ showed a signal at $\delta=$ $57.5 \mathrm{ppm}$ for the spiro carbon and the signal at $\delta=39.3$ ppm correlated to the $\mathrm{N}$-methyl group (Figure 2). In the DEPT 135 spectrum of $\mathbf{5 b}$ the $\mathrm{N}-\mathrm{CH}_{2}$ carbon resonated at $\delta=$ $60.1 \mathrm{ppm}$ and the $\mathrm{O}-\mathrm{CH}_{2}$ carbon of the chromanone moiety showed a negative signal at $\delta=68.3 \mathrm{ppm}$. The furanose ring attached to the pyrrolidine carbon showed a peak at $\delta=$ $64.5 \mathrm{ppm}$ and the peak at $\delta=48.2 \mathrm{ppm}$ correlating to the benzyl attached pyrrolidine ring carbon were confirmed by DEPT-135 and ${ }^{1} \mathrm{H}-{ }^{13} \mathrm{C}$ correlation. The furanose ring carbons showed signals at $\delta=104.7,101.4,81.3$, and $156.0 \mathrm{ppm}$, respectively, which were confirmed by DEPT- 135 and ${ }^{1} \mathrm{H}-{ }^{13} \mathrm{C}$ correlation. The peak at $\delta=192.1 \mathrm{ppm}$ corresponds to the chromanone carbonyl group. Moreover, the cycloadduct $\mathbf{5 b}$ exhibited a peak at $m / z 519.3\left[\mathrm{MH}^{+}\right]$in the mass spectrum. All these spectroscopic features support the conclusion that the cycloaddition proceeded in a highly regioselective manner, with elimination affording a single regioisomer. The benzyloxy group elimination in the above reaction is well supported by previous reports. ${ }^{22}$

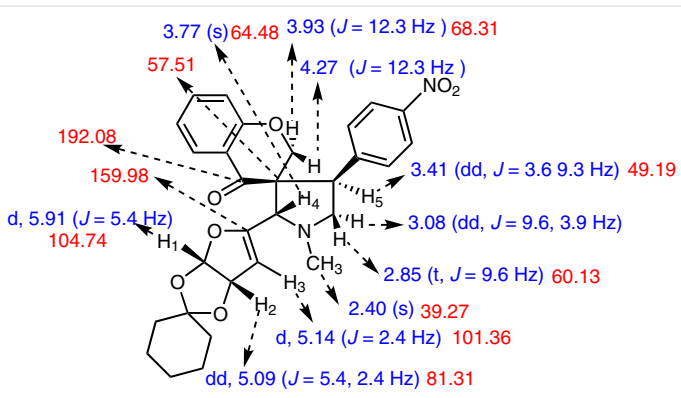

Figure 2 Key NMR assignments in compound $\mathbf{5 b}$

Encouraged by this result, we extended the reaction of 3-arylidene chroman-4-ones 1a-c to different azomethine ylides generated from cyclic amino acids proline $\mathbf{6}$, pipecolinic acid 7, thiazolidine-4-carboxylic acid 10, and sugar aldehyde $\mathbf{3}$ under the optimized conditions to give glycosyl spirochromanono pyrrolizidines/thiolizidines (8a-c, 9a-c, and 11a-c) in good yields (Table 1). The reaction gave a single product in all cases, as evidenced by TLC analysis. The cycloaddition was found to be highly regioselective and the $O$-benzyl group was found to be eliminated in all cases (Scheme 3 and Scheme 4$){ }^{23}$ The structure and regiochemistry of the cycloadducts were established by IR, ${ }^{1} \mathrm{H},{ }^{13} \mathrm{C}$, DEPT-135, 2D NMR spectroscopic and mass spectrometric studies as described for $\mathbf{5 b}$.
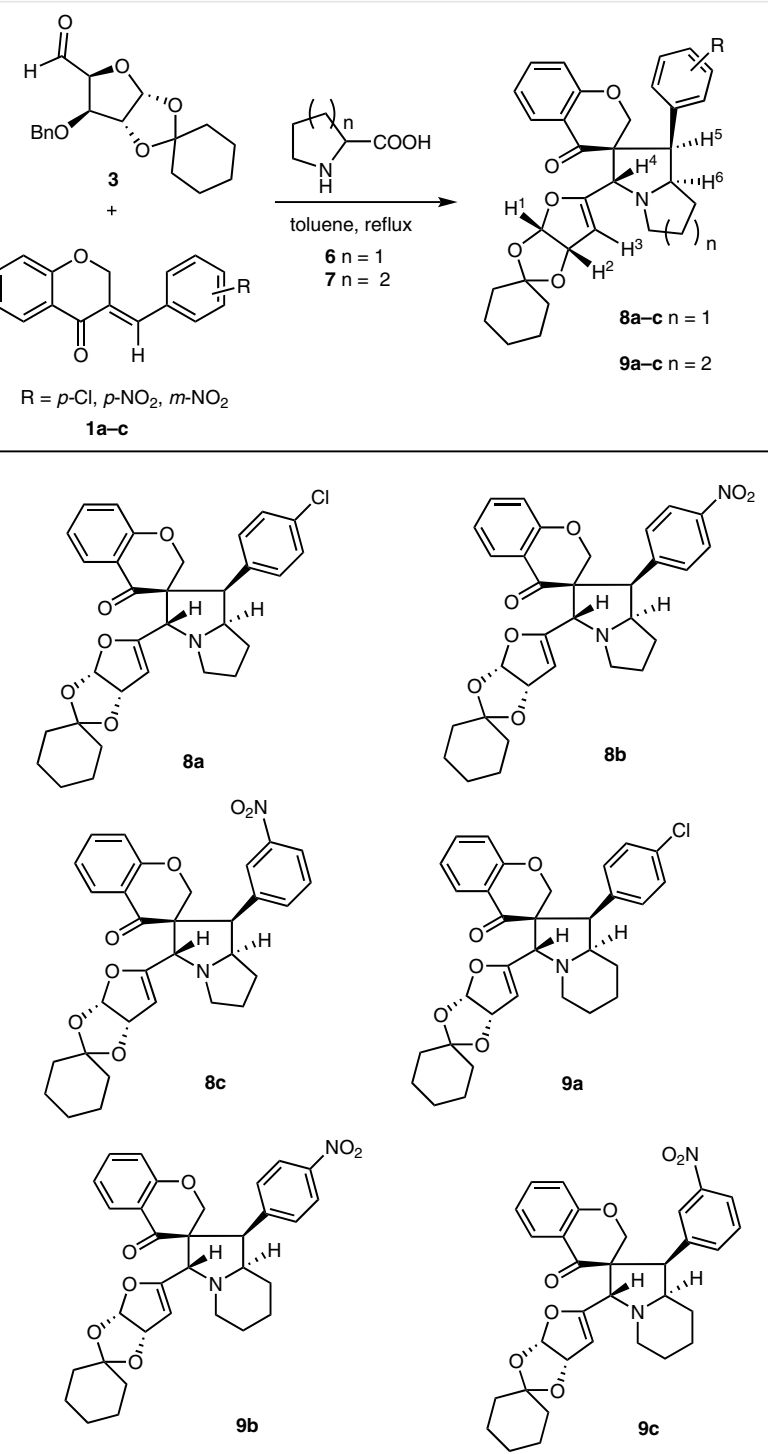

Scheme 3 Synthesis of sugar-fused spirochromanono pyrrolizidines

The reaction was investigated in a series of solvent systems such as acetonitrile, methanol, and toluene to establish the best reaction conditions. Among the solvents used, toluene was found to be the best in terms of better yields and short reaction time (Table 1 ). 

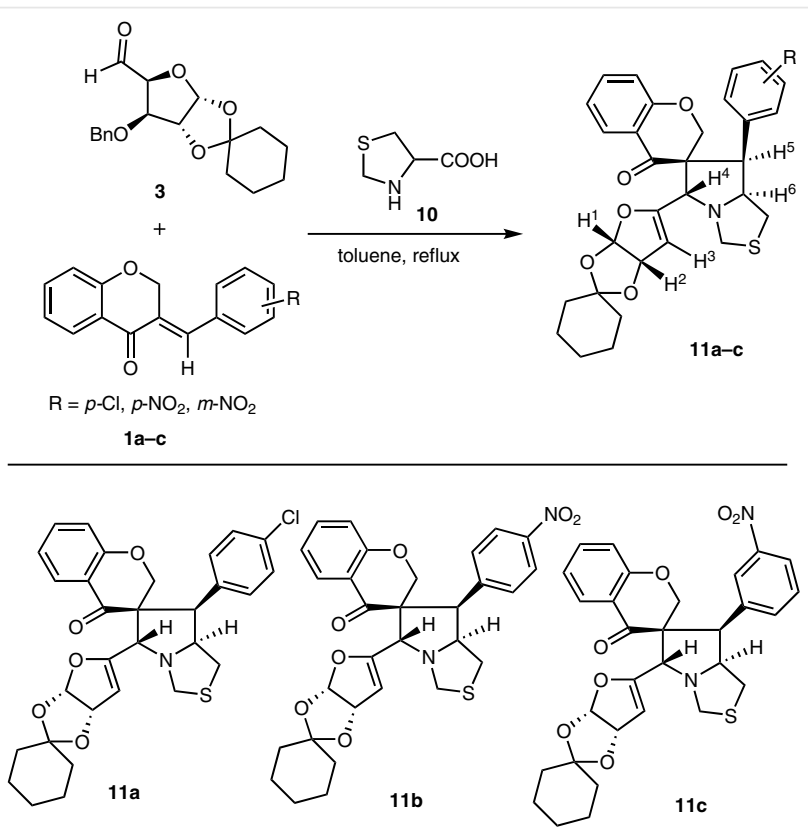

Scheme 4 Synthesis of sugar-fused spirochromanono thiolizidines

Table 1 Cycloaddition Reaction of O-Benzyl Tethered Sugar Aldehyde and Cyclic/Acyclic Amino Acid with 3-Arylidene Chroman-4-ones in Different Solvents

\begin{tabular}{|c|c|c|c|c|c|c|}
\hline \multirow[t]{2}{*}{ Compound } & \multicolumn{2}{|l|}{ Toluene } & \multicolumn{2}{|l|}{ Methanol } & \multicolumn{2}{|c|}{ Acetonitrile } \\
\hline & Time (h) & Yield (\%) & Time (h) & Yield (\%) & Time (h) & Yield (\%) \\
\hline $5 a$ & 8 & 64 & 9 & 48 & 9 & 42 \\
\hline $5 b$ & 8 & 66 & 9 & 43 & 9 & 49 \\
\hline $5 c$ & 8 & 62 & 9 & 49 & 9 & 48 \\
\hline $8 a$ & 8 & 64 & 9 & 47 & 9 & 51 \\
\hline $8 b$ & 8 & 65 & 9 & 51 & 9 & 45 \\
\hline $8 c$ & 8 & 61 & 9 & 46 & 9 & 44 \\
\hline $9 a$ & 8 & 60 & 9 & 46 & 9 & 41 \\
\hline $9 b$ & 8 & 62 & 9 & 50 & 9 & 49 \\
\hline $9 c$ & 8 & 62 & 9 & 41 & 9 & 44 \\
\hline $11 a$ & 8 & 61 & 9 & 42 & 9 & 41 \\
\hline $11 b$ & 8 & 67 & 9 & 40 & 9 & 42 \\
\hline $11 c$ & 8 & 67 & 9 & 43 & 9 & 47 \\
\hline
\end{tabular}

In conclusion, the synthetic utility of a carbohydrate scaffold as an azomethine ylide in 1,3-dipolar cycloaddition reaction has been studied and a series of sugar-fused spirochromanono heterocycles has been synthesized.

\section{Funding Information}

We thank the Council of Scientific and Industrial Research, New Delhi, India (Award Letter No: 09/115(0733)/2011-EMR-I) for financial support.

\section{Supporting Information}

Supporting information for this article is available online at https://doi.org/10.1055/s-0036-1588520.

\section{References and Notes}

(1) Levy, D. E.; Fügedi, P. The Organic Chemistry of Sugars; Taylor \& Francis/CRC Press: Boca Raton, 2005.

(2) (a) Danishefsky, S. J.; Allen, J. R. Angew. Chem. Int. Ed. 2000, 39, 836. (b) Allen, J. R.; Harris, C. R.; Danishefsky, S. J. J. Am. Chem. Soc. 2001, 123, 1890.

(3) Hosoya, T.; Takashiro, E.; Matsumoto, T.; Suzuki, K. Tetrahedron Lett. 1994, 35, 4591.

(4) Ferguson, N. M.; Cummings, D. A. T.; Cauchemez, S.; Fraser, C.; Riley, S.; Meeyai, A.; Iamsirithaworn, S.; Burke, D. S. Nature 2005, 437, 209.

(5) (a) Cipolla, L.; La Ferla, B.; Nicotra, F. Curr. Top. Med. Chem. 2003, 3, 485. (b) Harris, C. M.; Harris, T. M. J. Am. Chem. Soc. 1982, 104, 363.

(6) Kim, H. O.; Ahn, S. K.; Alves, A. J.; Beach, J. W.; Jeong, L. S.; Choi, B. G.; Roey, P. V.; Schinazi, R. F.; Chu, C. K. J. Med. Chem. 1992, 35 , 1987.

(7) (a) El Ashry, E. S. H. Heterocycles from Carbohydrate Precursors; Springer Science \& Business Media: Berlin/Heidelberg, 2007. (b) Frieder, W. L. Acc. Chem. Res. 2002, 35, 728.

(8) (a) Prasanna, R.; Purushothaman, S.; Raghunathan, R. Tetrahedron Lett. 2010, 51, 4538. (b) Naga Siva, Rao. J.; Raghunathan, R. Tetrahedron Lett. 2015, 56, 1539.

(9) (a) Sarotti, A. M.; Spanevello, R. A.; Suarez, A. G.; Echeverria, G. A.; Piro, O. E. Org. Lett. 2012, 14, 2556. (b) Karanjule, N. S.; Shankar, D. M.; Tarun, S.; Sushma, G. S.; Vedavati, G. P.; Dilip, D. D. J. Org. Chem. 2005, 70, 1356. (c) Bokor, E.; Sandor, K.; Tibor, D.; Gergely, P.; Laszlo, S. Med. Chem. Lett. 2015, 12, 1215.

(10) (a) Emami, S.; Ghanbarimasir, Z. Eur. J. Med. Chem. 2015, 93, 539.

(11) Ashok, D.; Madhuri, E. V. L.; Sarasija, M.; Sree Kanth, S.; Vijjulatha, M.; Malini, D. A.; Sagurthi, S. R. RSC Adv. 2017, 7, 25710.

(12) Mujahid, M.; Gonnade, R. G.; Yogeeswari, P.; Sriram, D.; Muthukrishnan, M. Bioorg. Med. Chem. Lett. 2013, 23, 1416.

(13) (a) Jorge, A. P.; Horst, H.; De Souza, E.; Pizzolatti, M. G.; Silva, F. R. M. B. Chem. Biol. Interact. 2004, 149, 89. (b) Matsuda, H.; Morikawa, T.; Yoshikawa, M. Pure Appl. Chem. 2002, 74, 1301.

(14) Tasdemir, D.; Kaiser, M.; Brun, R.; Yardley, V.; Schmidt, T. J.; Tosun, F.; Ruedi, P. Antimicrob. Agents Chemother. 2006, 50, 1352.

(15) (a) Matthew, P. B. J. Med. Chem. 2015, 58, 525. (b) Huang, T.; Sun, J.; Wang, Q.; Gao, J.; Liu, Y. Molecules 2015, 20, 16221.

(16) Walsh, J.; Bell, A. Curr. Pharm. Des. 2009, 15, 2970.

(17) (a) Gallos, J. K.; Koumbis, A. E. Curr. Org. Chem. 2003, 7, 397. (b) Benltifa, M.; Vidal, S.; Gueyrard, D.; Goekjian, P. G.; Msaddek, M.; Praly, J.-P. Tetrahedron Lett. 2006, 47, 6143.

(18) (a) Rajesh, R.; Raghunathan, R. Synlett 2013, 2107. (b) Kathiravan, S.; Raghunathan, R. Synlett 2010, 952. (c) Jayashankaran, J.; Manian, R. D. R. S.; Raghunathan, R. Synthesis 2006, 1028.

(19) Xavier, N. M.; Rauter, A. P. Carbohydr. Res. 2008, 343, 1523.

(20) Bennett, P.; Donnelly, J. A.; Meaney, D. C.; Boyle, P. O. J. Chem. Soc., Perkin Trans. 1 1972, 1554. 
(21) Experimental procedure and characterization data for cycloadduct 5b: A solution of 0 -benzyl tethered sugar aldehyde $\mathbf{3}$ $(0.1 \mathrm{~g}, 0.31 \mathrm{mmol})$, sarcosine $2(0.028 \mathrm{~g}, 0.346 \mathrm{mmol})$ and 3arylidene chroman-4-one $\mathbf{1 b}(0.088 \mathrm{~g}, 0.31 \mathrm{mmol})$ was heated to reflux in anhydrous toluene for $8 \mathrm{~h}$. The crude product was purified by column chromatography (hexane/EtOAc, 99:1) to give $\mathbf{5 b}$ as a pale-yellow liquid $(0.11 \mathrm{~g}, 66 \%)$. IR (KBr): 1342 , 1520, $1690 \mathrm{~cm}^{-1}$. ${ }^{1} \mathrm{H}$ NMR $\left(\mathrm{CDCl}_{3}, 300 \mathrm{MHz}\right): \delta=1.49$ (br s, $10 \mathrm{H}), 2.40(\mathrm{~s}, 3 \mathrm{H}), 2.85(\mathrm{t}, J=9.3 \mathrm{~Hz}, 1 \mathrm{H}), 3.08(\mathrm{dd}, J=3.6$, $9.3 \mathrm{~Hz}, 1 \mathrm{H}), 3.41(\mathrm{dd}, J=3.6,9.3 \mathrm{~Hz}, 1 \mathrm{H}), 3.77(\mathrm{~s}, 1 \mathrm{H}), 3.93(\mathrm{~d}$, $J=12.3 \mathrm{~Hz}, 1 \mathrm{H}), 4.27(\mathrm{~d}, J=12.3 \mathrm{~Hz}, 1 \mathrm{H}), 5.09$ (dd, $J=2.4$, $5.4 \mathrm{~Hz}, 1 \mathrm{H}), 5.14(\mathrm{~d}, J=2.4 \mathrm{~Hz}, 1 \mathrm{H}), 5.91(\mathrm{~d}, J=5.4 \mathrm{~Hz}, 1 \mathrm{H})$, 6.69-8.07 (m, $8 \mathrm{H}) .{ }^{13} \mathrm{C}$ NMR $(75 \mathrm{MHz}): \delta=22.89,22.91,23.81$, 35.94, 36.49, 39.27, 48.19, 57.51, 60.13, 64.48, 68.33, 81.31, 101.36, 104.74, 111.63, 116.50, 117.99, 120.59, 122.18, 122.77, $122.95,127.30,128.63,129.44,135.45,146.06,147.46,157.43$, 159.98, 192.08. MS (ESI); $m / z=519.1\left[\mathrm{M}^{+}+1\right]$. Anal. Calcd for $\mathrm{C}_{29} \mathrm{H}_{30} \mathrm{~N}_{2} \mathrm{O}_{7}$ : C, 67.17; H, 5.83; N, 5.40; found: C, 67.24; H, 5.81; $\mathrm{N}, 5.32$

(22) Karthikeyan, K.; Senthil, Kumar. R.; Muralidharan, D.; Perumal, P. T. Tetrahedron Lett. 2009, 50, 7175.
(23) Experimental procedure and characterization data for cycloadduct 11b: A solution of $O$-benzyl tethered sugar aldehyde 3 $(0.1 \mathrm{~g}, 0.31 \mathrm{mmol})$, thiazolidine-4-carboxylic acid $10(0.042 \mathrm{~g}$, $0.346 \mathrm{mmol})$ and 3-arylidene chroman-4-one $\mathbf{1 b}(0.088 \mathrm{~g}, 0.31$ $\mathrm{mmol}$ ) was heated to reflux in anhydrous toluene for $8 \mathrm{~h}$. The crude product was purified by column chromatography (hexane/EtOAc, 98:2) to give $\mathbf{1 1 b}$ as a pale-yellow liquid $(0.12 \mathrm{~g}$, 67\%). IR (KBr): 1684, 1551, $1352 \mathrm{~cm}^{-1} .{ }^{1} \mathrm{H} \mathrm{NMR}\left(\mathrm{CDCl}_{3}, 300\right.$ $\mathrm{MHz}): \delta=1.53$ (br s, $10 \mathrm{H}), 2.39(\mathrm{dd}, J=5.1,9.3 \mathrm{~Hz}, 1 \mathrm{H}), 3.37$ (dd, $J=5.1,9.3 \mathrm{~Hz}, 1 \mathrm{H}), 3.48(\mathrm{~d}, J=11.4 \mathrm{~Hz}, 1 \mathrm{H}), 3.83(\mathrm{~s}, 1 \mathrm{H})$, $4.05(\mathrm{~d}, J=3.6 \mathrm{~Hz}, 1 \mathrm{H}), 4.11(\mathrm{~d}, J=11.4 \mathrm{~Hz}, 1 \mathrm{H}), 4.23-4.28(\mathrm{~m}, 1$ H), $4.49(\mathrm{~d}, J=12 \mathrm{~Hz}, 1 \mathrm{H}), 4.61(\mathrm{~d}, J=12 \mathrm{~Hz}, 1 \mathrm{H}), 4.77(\mathrm{dd}, J=$ 2.4, $5.4 \mathrm{~Hz}, 1 \mathrm{H}), 5.23(\mathrm{~d}, J=2.4 \mathrm{~Hz}, 1 \mathrm{H}), 5.86(\mathrm{~d}, J=5.4 \mathrm{~Hz}, 1 \mathrm{H})$, 6.82-8.09 (m, $8 \mathrm{H}) .{ }^{13} \mathrm{C}$ NMR (75 MHz): $\delta=23.57,23.72,24.69$, $35.42,37.26,43.11,44.10,55.53,58.68,71.59,71.69,72.78$, $82.74,99.83,104.32,113.27,117.78,123.77,125.90,127.75$, 128.21, 128.63, 129.65, 136.62, 136.98, 146.14, 153.34, 167.12, 194.70. MS (ESI); $m / z=563.3\left[\mathrm{M}^{+}+1\right]$. Anal. Calcd for $\mathrm{C}_{30} \mathrm{H}_{30} \mathrm{~N}_{2} \mathrm{O}_{7} \mathrm{~S}$ : C, 64.04; $\mathrm{H}, 5.37 ; \mathrm{N}, 4.98$; found: $\mathrm{C}, 64.12 ; \mathrm{H}, 5.41$; $\mathrm{N}, 4.87$ 